\title{
Modeling shows that alternative soil management can decrease greenhouse gases
}

by Steven De Gryze, Maria V. Albarracin, Rosa Català-Luque, Richard E. Howitt and Johan Six

\section{Agricultural management has a} significant impact on the amount of greenhouse gases emitted by cropped fields. Alternative practices such as winter cover cropping and avoiding overfertilization can decrease the total amount of greenhouse gases that are produced. Policymakers are considering a structure in which parties (such as factories) who exceed their greenhouse-gas emissions cap can pay incentives to encourage farmers to adopt practices that curb greenhouse gases. Based on data from field studies and an ecosystem computer model, we assessed impacts on yields and the total potential for reducing greenhousegas emissions of certain alternative practices in California.

W ithin the California Global Warming Solutions Act of 2006 (AB32), a legally binding cap-and-trade approach for limiting greenhouse-gas emissions is being developed. Parties who exceed their greenhouse-gas emissions allowance would be able to meet their cap either by buying excess allowance from other parties or by financing activities that decrease the amount of greenhouse gases emitted to the atmosphere.

It has been suggested that agriculture could take part in California's carbon market; alternative agricultural practices such as reduced tillage, cover cropping and organic farming can cut greenhouse-gas emissions. An evaluation of the potential for this market participation requires answers to three questions. First, are yields affected by these alternative practices? Second, how much can these practices reduce greenhouse-gas emissions? Third, given the costs of these practices and
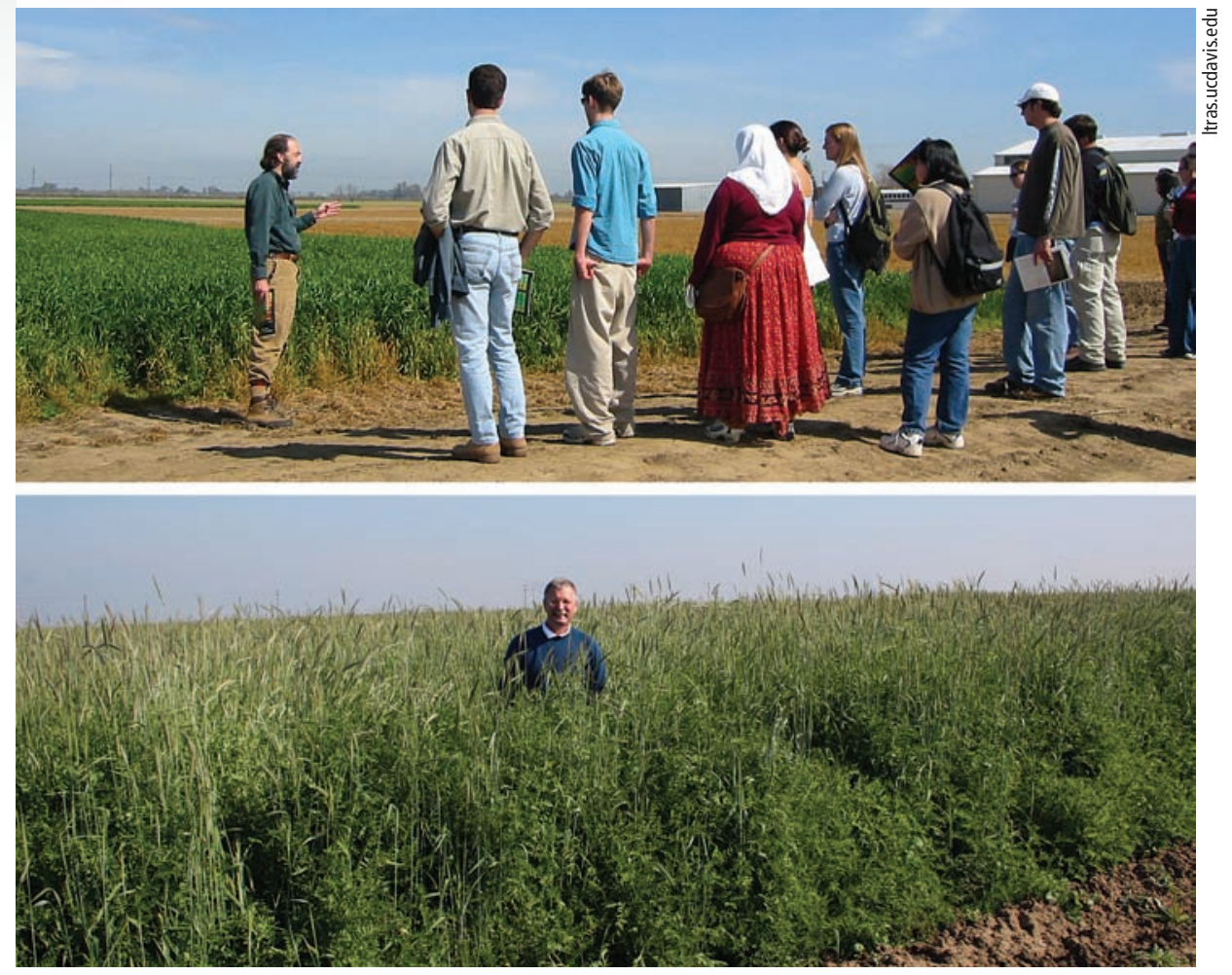

To develop computer models to estimate the contribution of alternative agricultural practices to carbon sequestration, researchers utilized data from a variety of California field studies. Top, the Long-Term Research on Agricultural Systems (LTRAS) project at UC Davis was initiated in 1993 as a 100-year experiment (shown in 2003). Above, Jeff Mitchell of UC Cooperative Extension and colleagues have been studying conservation tillage and cover cropping at the UC West Side Research and Extension Center.

potential decreases in yield, how much should farmers be paid to change their management? We focus on the first two questions; for approaches to the third, see Howitt et al. (2009) (page 91).

California has a diverse range of microclimates, soil types and crops; and crops are grown in complex rotation schedules. As a consequence, detailed analysis is needed to model this diversity and complexity. It is impractical to continuously monitor and measure greenhouse-gas fluxes across and among all combinations of crop rotations, soil types and microclimates, as well as their interactions. Rather than field measurements, this study uses an ecosystem computer model, which is the preeminent tool to simulate greenhouse-gas exchanges between land and atmospheric fluxes (Smith et al. 1997). This model study focuses only on the most important annual crops and does not include orchards or vineyards.

\section{Agricultural greenhouse gases}

Although carbon dioxide $\left(\mathrm{CO}_{2}\right)$ is the best-known greenhouse gas, there are two other greenhouse gases produced or consumed by soil microorganisms: methane $\left(\mathrm{CH}_{4}\right)$ and nitrous oxide $\left(\mathrm{N}_{2} \mathrm{O}\right)$ (Conrad 1996). The yearly total of carbon dioxide exchanges between the land and atmosphere is usually quantified by changes in organic carbon levels in the soil. Alternative practices, such as conservation tillage or those that increase plant production, can capture more atmospheric carbon in the soil because the soil is less disturbed and/or more crop residues are produced, promoting the conversion of crop residues into soil organic carbon. In other words, atmospheric carbon dioxide can be sequestered in soil organic carbon through decreased soil disturbance and/or increased crop production. 
Methane is produced primarily in rice systems by so-called methanogenic bacteria that live in close proximity to the fine roots of the rice plant. In addition, other bacteria, called methanotrophic bacteria, can transform methane into carbon dioxide in well-aerated soils, which includes most of those not cropped with rice in California; this process is called methane oxidation.

Microorganisms in the soil produce nitrous oxide if excess mineral nitrogen, readily decomposable carbon and moisture are simultaneously present; the processes involved are called nitrification and denitrification.

The three greenhouse gases produced and/or consumed by soils and crops differ in their "forcing" of global warming. More specifically, one molecule of nitrous oxide gas has the same global-warming effect as 289 molecules of carbon dioxide, while one molecule of methane has the same global-warming effect as 25 molecules of carbon dioxide. When taking into account these variable impacts, the total combined potential of a mixture of the three greenhouse gases is called global warming potential (GWP) and is expressed in carbon dioxide equivalents $\left(\mathrm{CO}_{2} \mathrm{e}\right)$. This concept makes it possible to compare and rank agricultural practices according to their potential to cause or mitigate global warming.

The aims of this study were to: (1) calibrate an ecosystem computer model for California conditions using data from several long-term field experiments, (2) use the calibrated model to evaluate changes in crop yields resulting from alternative management practices and (3) evaluate the biological potential of greenhouse-gas mitigation by these practices.

\section{Long-term field experiments}

Before an ecosystem computer model can be applied to a certain region, it must be adjusted for the specific conditions of that area, such as the typical management practices, number of tillage passes, irrigation regime, climate, and planting and harvesting periods. For this purpose, we selected four longterm agricultural research experiments in California with which to adjust and test the model.

LTRAS. The Long-term Research on Agricultural Systems (LTRAS) project (http://ltras.ucdavis.edu) was established in 1993 by researchers at UC Davis. We used data from four corn-tomato rotations that are investigated at LTRAS: (1) a conventionally managed system, (2) a legume cover crop followed first by unfertilized corn and then by conventionally fertilized tomato, (3) an organic system with poultry manure amendments and no chemical fertilizer and (4) a winter legume cover crop. In addition, each of the three replicate plots were split in half between standard and conservation tillage (Denison et al. 2004).

SAFS. The Sustainable Agriculture Farming Systems (SAFS) project (http:// safs.ucdavis.edu) was conducted at UC Davis from 1989 through 2000. Data from the following three SAFS systems was used: (1) a conventionally managed system under a 4-year, tomatosafflower-corn-wheat-bean rotation, (2) a similar 4-year system with the addition of legume cover crops preceding each summer crop and (3) a 2-year, conventionally managed tomato-wheat rotation (Clark et al. 1999).

West Side REC. The West Side

Research and Extension Center (WSREC) in Five Points has four replicated tomatocotton rotations comparing standard and conservation-tillage practices with and without winter cover cropping. The conservation-tillage systems still included midseason cultivation within the furrows for tomato production and the undercutting of cotton after harvest (Mitchell et al. 2008).
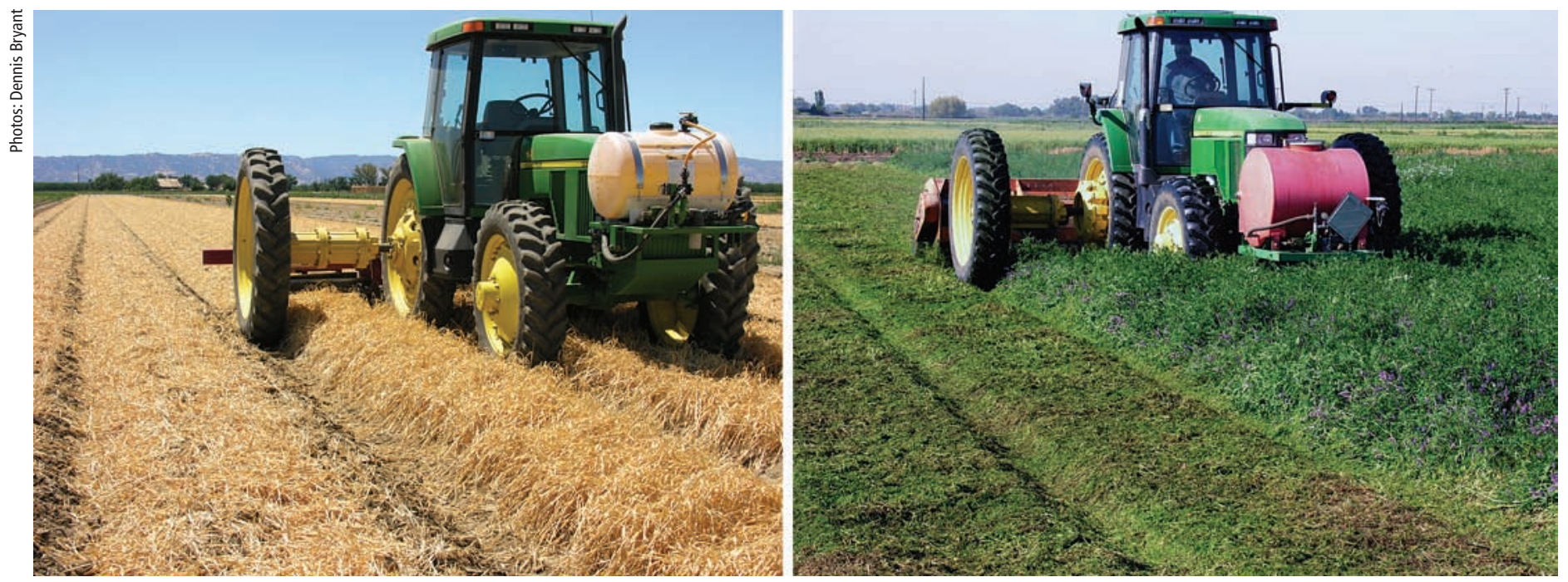

The Sustainable Agriculture Farming Systems (SAFS) project at UC Davis has compared conventional and alternative farming systems since 1988. In plots at the Russell Ranch Sustainable Agriculture Facility, where SAFS experiments have taken place, left, a winter wheat cover crop is roll-chopped and left as surface residue. Right, commonly practiced flail mowing shreds the cover-crop biomass into a slurry before its incorporation into the soil. 


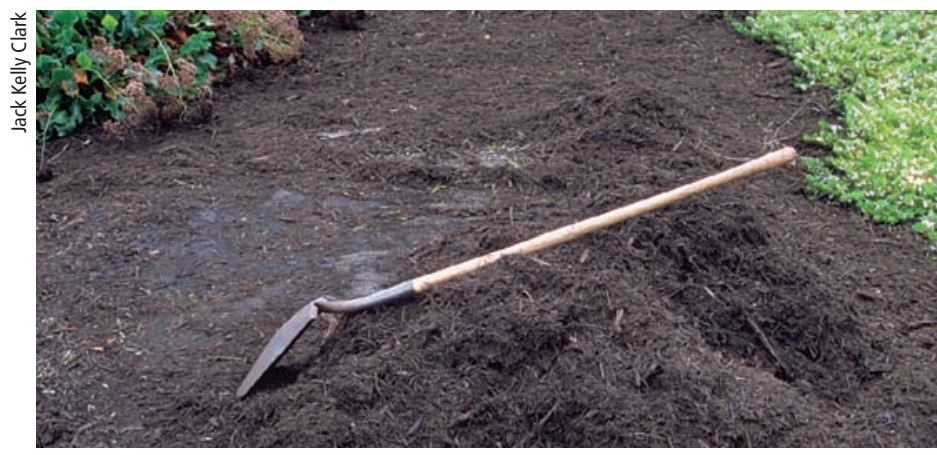

The computer model incorporated crop management and environmental factors to compare a range of cultural practices, such as the addition of compost mulch (shown).

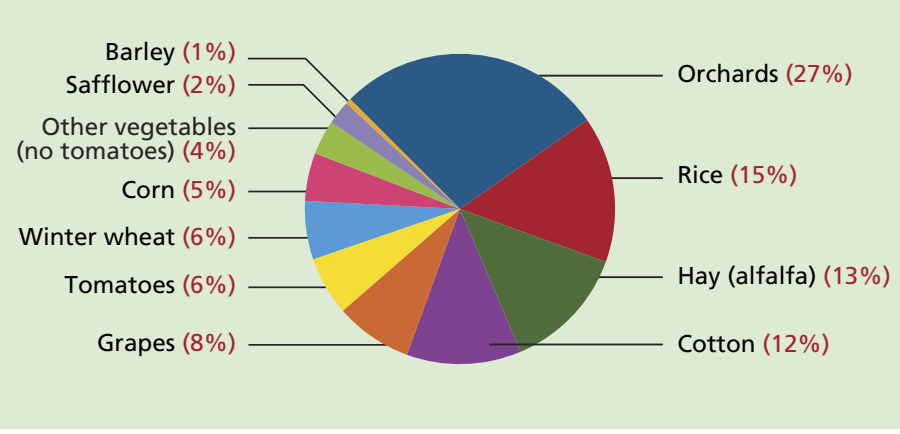

Fig. 1. Most important crops studied in 10 counties of the Sacramento and San Joaquin valleys. Source: USDA 2002.
Field 74. Field 74 was established in 2002 near Davis. The field was split into conservation- and standard-tillage halves. Sampling points were established across the field using a uniform grid with 70-yard (64-meter) spacing. Wheat was planted in fall 2002 and harvested in spring 2003. Corn was grown in 2004 and sunflower in 2005. During 2006, the last year of the experiment, chickpea was grown without fertilizer (Lee et al. 2006).

\section{Ecosystem model}

The DAYCENT computer model was used to simulate crop yields and greenhouse-gas emissions under the different alternative management practices considered (Del Grosso et al. 2000). This DAYCENT model is a daily version of the well-known CENTURY ecosystem model, which has a monthly time interval (Parton et al. 1987). The DAYCENT model simulates all major processes that affect the dynamics of soil carbon and nitrogen, including plant production, water flow, heat transport, soil organic carbon decomposition, nitrification and denitrification, and methane oxidation. Because the production of methane is not simulated, however, the predicted reductions in greenhouse-gas emissions for rice systems are provisional and should be used only as coarse indicators. The crop submodel simulates plant growth, plant tissue carbon-to-nitrogen ratios, carbon allocation between roots and shoots, and growth responses to light and temperature. A variety of management options can be specified, including crop type, tillage, fertilization, the addition of organic matter such as manure, harvest with a specified amount of residue removal, drainage, irrigation, burning and grazing intensity.
Data from the four field experiments was used to adjust the model parameters. First, simulated soilmoisture contents were checked against measured values from Field 74 and the LTRAS site. Parameters such as saturated hydraulic conductivity, or the wilting point, were fine tuned within the model. Second, predicted crop yields and dry-matter production were verified using published and measured root-to-shoot ratios, harvest indexes (ratio of harvestable part over total aboveground biomass) and carbon-to-nitrogen ratios. After this was accomplished, the amounts of standing stubble and plant residue litter were checked and compared with measured data and literature values. If necessary, parameters controlling root or shoot death were modified. Next, tillage intensity was altered until changes in soil carbon corresponded to those observed. Finally, modeled nitrous oxide fluxes were verified with data from Field 74 and compared to data from an extensive literature review (Stehfest and Bouwman 2006). Specific parameters controlling soil moisture and nitrous oxide production were further adjusted.

\section{Simulation parameters}

The Sacramento and San Joaquin valleys were considered separately in the simulations because these two regions differ substantially in climate, soil type and agricultural management. The simulations in the Sacramento Valley were carried out in eight counties - Butte, Colusa, Glenn, Sacramento, Solano, Sutter, Yolo and Yuba, totaling about 1.6 million acres ( 0.7 million hectares) of agricultural land. The simulations in the San Joaquin Valley were carried out in two counties - Kings and Fresno, totaling about 1.5 million acres (0.6 million hectares) of agricultural land.

Due to a lack of testing data in woody perennial systems (vineyards and orchards), only annual and nonwoody perennial cropping systems (such as alfalfa) were considered in this study. The latter systems comprise about $64 \%$ of agriculture in the 10 counties studied. The study was limited to the seven most abundant crops in both valleys: rice, alfalfa, cotton, tomatoes, winter wheat, corn (for grain in the Sacramento Valley and silage in the San Joaquin Valley) and safflower (fig. 1). The "other vegetable" category was omitted due to the large number of different vegetables produced. Harvested area for the seven crops was $76 \%$ of the total harvested area of total annual crops from 1980 to 2006; vegetables were 30\% from 1980 to 2006 (of which 7\% was tomato, which we included). These annual crops are always cultivated in a rotation system together with other crops. Therefore, sunflower and melons (honeydew, cantaloupe and watermelon) - the most commonly rotated crops in the systems that we considered - were also included in the simulations. Data on crop rotations was extracted from Pesticide Use Reports, agricultural commissioners and survey data. Based on this information, 10-year crop rotation schedules were generated for 1997 through 2006.

Alternative management practices considered included conservation tillage, manure application and winter cover cropping, and all possible combinations of these practices. The winter cover crop simulated was a legume/ small-grain mixture with a carbon-tonitrogen ratio of 25 at plow down. It was planted 1 month after harvest of the preceding crop, and incorporated 
1 month before planting of the succeeding crop. A practice in which nitrogen fertilizer was reduced by $25 \%$ was also included. Winter cover cropping was not simulated for winter wheat. Alternative management practices were limited for alfalfa systems because they require almost no tillage or fertilization.

\section{Data sources, model adjustments}

Details on conventional management practices in the region (such as planting and harvesting dates, fertilization rates, irrigation amounts and pest management) were obtained from the four long-term field experiments described, the Agronomy Research and Information Center (http://agric.ucdavis.edu) and UC Davis cost and return studies (http:// coststudies.ucdavis.edu).

The most detailed geographical input data was used (fig. 2). We extracted soil data from the geographic information systems (GIS) database in the Natural Resources Conservation Service's Soil Survey Geographic Database, and used the crop-use and field-boundary GIS layer from the California Department of Water Resources (DWR). Solano and Placer counties were surveyed in 1994; Yuba County in 1995; Yolo County in 1997; Colusa, Glenn and Sutter counties in 1998; Butte County in 1999; Fresno and Sacramento counties in 2000; and Kings County in 2003. Daily climate data for 1.86-mile-by-1.86-mile (3-kilometer-by-3kilometer) grid cells from 1980 through 2003 was extracted from the DAYMET model (www.daymet.org) developed at the University of Montana. For 2004 until 2006, we obtained weather station data from the DWR California Irrigation Management Information System (www. cimis.water.ca.gov).

We adjusted the model for California conditions using data measured in the four long-term field experiments. Data on crop yields, dry matter production, soil organic carbon changes and nitrous oxide emissions was used to calibrate the model. Only the measured and modeled yields are presented here (fig. 3). The model was able to capture general yield trends in these experiments adequately. However, the yearly differences in yield due to climate and management within a crop were modeled less well. The model satisfactorily
Land-use data

from California Department of Water Resources

\section{Soils data}

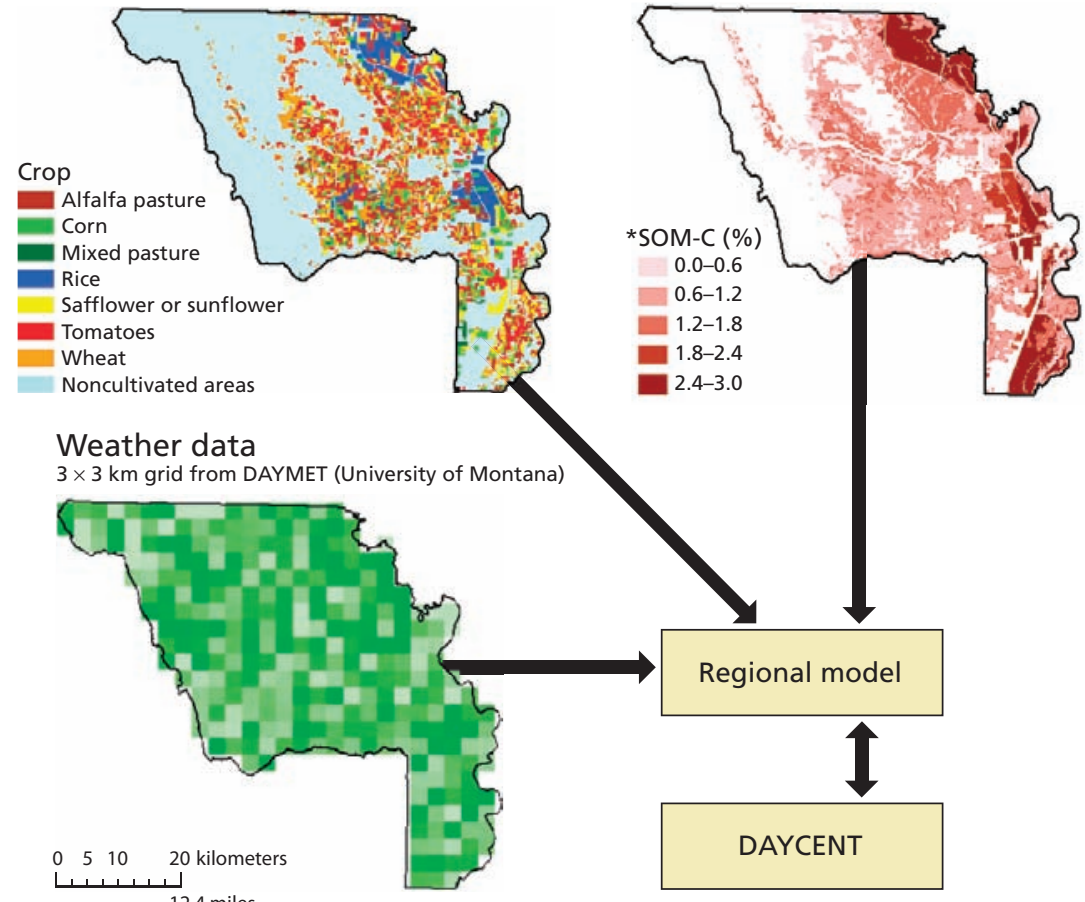

*Soil organic matter - carbon

Fig. 2. Data sources for regional modeling.

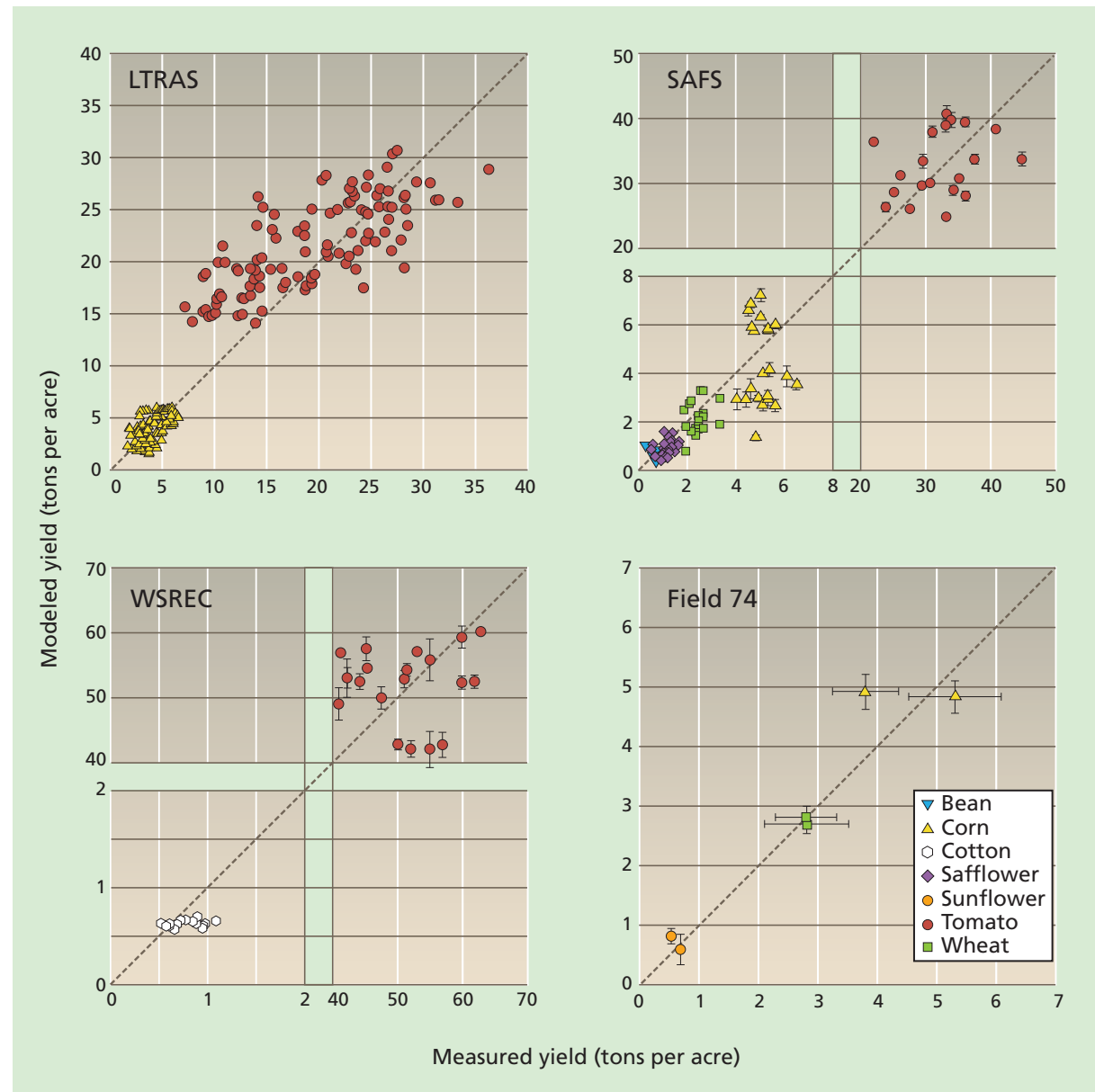

Fig. 3. Modeled versus measured yields across years, replicates, treatments and crops at four long-term field experiments in California. Error bars show \pm 1 standard deviation around modeled results. 


\section{Carbon offsets generated by increases in soil organic carbon are temporary and reversible, while those generated by decreases in nitrous oxide emissions are permanent.}

simulated observed changes in other measured data, such as soil organic carbon and nitrous oxide emissions (De Gryze et al., unpublished data).

\section{Yields and alternative management}

Once the computer model was calibrated for California conditions, it could be used to predict changes in yields under alternative management practices. The model predicted that most crop yields would be little affected by the alternative management practices that were considered in this study (table 1). Safflower showed the greatest predicted yield reduction, up to $13 \%$. Predicted yield reductions in other crops were generally less than $5 \%$.

These results are in agreement with those of the field experiments, showing that alternative practices like those studied here maintain yields when properly managed. For example, applying manure instead of mineral fertilizer did not affect corn yields (Miguez and Bollero 2005) or wheat yields in a study in a Mediterranean climate (Deria et al. 2003). The same was found for tomatoes in California (Drinkwater et al. 1995). At the LTRAS site, yield differences between conventional and manure treatments were obscured by the relatively larger yield variability caused by weather (Denison et al. 2004). At the SAFS site, there was only a yield decrease with two of the four organic treatments (Clark et al. 1999). Snapp et al. (2005) concluded that cover cropping frequently increases yields by up to $15 \%$, while Mitchell et al. (2008) reported a small decrease of $5 \%$ to $10 \%$ in some years. Likewise, conservation tillage at the WSREC site had a minimum impact on tomato and cotton yields and in general was found to maintain yields in California (Mitchell et al. 2008).

It may seem surprising that yields decreased only minimally when nitrogen fertilizer was reduced by $25 \%$. However, this is an indication that in many crop systems the conventional amount of fertilizer applied is above what is actually taken up by the crop. Overfertilization is a common practice in California, due to farmers' desires to

\begin{tabular}{|c|c|c|c|c|c|c|c|c|}
\hline Tillage & Conv.t & Conserv. & Conv. & Conserv. & Conv. & Conserv. & Conv. & Conserv. \\
\hline Fertilizer & $\begin{array}{c}\text { Mineral, } \\
75 \%\end{array}$ & Mineral & Mineral & Mineral & Manure & Manure & Manure & Manure \\
\hline Cover crop & No & No & Yes & Yes & No & No & Yes & Yes \\
\hline \multicolumn{9}{|c|}{ yield change (\%) } \\
\hline \multicolumn{9}{|c|}{ Sacramento Valley } \\
\hline Alfalfa & -‡ & - & - & - & - & - & - & - \\
\hline Corn & - & 3 & - & - & - & -3 & -2 & -3 \\
\hline Rice & - & - & - & - & - & -5 & -4 & - \\
\hline Safflower & -13 & - & 4 & 4 & -4 & - & - & -6 \\
\hline Sunflower & - & - & - & - & - & - & - & - \\
\hline Tomato & -4 & - & - & - & - & -4 & -4 & -3 \\
\hline Wheat & - & - & - & - & -4 & -3 & -2 & - \\
\hline \multicolumn{9}{|c|}{ San Joaquin Valley } \\
\hline Alfalfa & - & & - & 3 & 3 & - & - & 4 \\
\hline Corn & - & & - & - & - & - & - & - \\
\hline Cotton & -2 & & - & -4 & -4 & - & - & -5 \\
\hline Melon & -7 & - & - & - & - & - & - & -3 \\
\hline Rice & - & - & - & -3 & -3 & - & - & -4 \\
\hline Tomato & -5 & - & - & -4 & -4 & - & - & -4 \\
\hline Wheat & - & - & - & - & - & -3 & -4 & -3 \\
\hline \multicolumn{9}{|c|}{$\begin{array}{l}\text { * Conventional practices }=100 \% \text { mineral fertilizer, no cover crop and conventional tillage. Values are } \\
\text { averages over individual fields, } 1997-2006 \text {. Crops are grown in their typical rotations. Values are biophysical } \\
\text { potentials not reflecting limitations of combining practices. }\end{array}$} \\
\hline
\end{tabular}

minimize the risk of yield reductions due to nitrogen limitation and the low price of nitrogen fertilizer (Cassman et al. 2002). Fertilizer rates are selected so that the least productive parts of a field still receive sufficient nitrogen. Experimental evidence for the sustainability of similar low-input systems can be found in Clark et al. (1999) and Denison et al. (2004).

\section{Reduction potentials evaluated}

The emissions reductions due to winter cover cropping, manure application or conservation tillage alone were modest and between -0.2 and -0.6 (metric ton carbon dioxide equivalents per acre per year $\left(\mathrm{MtCO}_{2} \mathrm{e} / \mathrm{acre} / \mathrm{yr}\right)$ or -0.5 and -1.4 metric tons carbon dioxide equivalents per hectare per year $\left(\mathrm{MtCO}_{2} \mathrm{e} /\right.$ ha/yr). However, by combining these individual practices, larger emissions reductions are possible. Most markedly, combining manure application with winter cover cropping seems to be an efficient option for curbing greenhousegas emissions. Although combining all three alternative practices has the greatest potential, this does not seem feasible from a farmer's practical standpoint. Excluding this option, potential reductions in greenhouse-gas emissions ranged from -0.28 to $-1.05 \mathrm{MtCO}_{2} \mathrm{e} /$ acre/yr ( -0.7 to $\left.-2.6 \mathrm{MtCO}_{2} \mathrm{e} / \mathrm{ha} / \mathrm{yr}\right)$ for the Sacramento Valley, and from -0.2 to $-0.77 \mathrm{MtCO}_{2} \mathrm{e} /$ acre/yr ( -0.5 to -1.9 $\mathrm{MtCO}_{2} \mathrm{e} / \mathrm{ha} / \mathrm{yr}$ ) for the San Joaquin Valley (fig. 4).

Note that these values do not include further reductions in carbon dioxide emissions due to reduced fuel use under conservation tillage, which could account for an extra 0.1 to $0.2 \mathrm{MtCO}_{2} \mathrm{e} /$ acre/yr (0.25 to $0.50 \mathrm{MtCO}_{2} \mathrm{e} / \mathrm{ha} / \mathrm{yr}$ ) (data not shown). In addition, these values do not account for greenhouse gases produced during the production, storage and transport of manure and mineral fertilizer.

In general, cropping systems in the Sacramento Valley showed more potential to mitigate greenhouse gases than those in the San Joaquin Valley. Probably, warmer temperatures in the San Joaquin Valley increase the decom- 
position of soil organic carbon compared to that of the Sacramento Valley. In addition, the decreases in nitrous oxide emissions related to manure application were much less apparent at warmer temperatures.

\section{Reducing greenhouse gases}

Agricultural greenhouse-gas emissions can be curbed (and carbon credits generated) in three ways: by increasing soil organic carbon, decreasing nitrous oxide and methane emissions, and decreasing fuel use by field equipment. Whether the decrease in greenhouse-gas emissions comes from an increase in soil organic carbon, or from decreases in nitrous oxide emissions, severely affects the longevity or permanence (and hence the price) of the generated carbon offsets. This is because carbon offsets generated by increases in soil organic carbon are temporary and reversible, while those generated by decreases in nitrous oxide emissions are permanent.

Soil organic carbon. Increases in soil organic carbon accounted for $70 \%$ to $90 \%$ of the carbon offsets from alternative management practices such as winter cover cropping and conservation tillage. This creates a potential legacy for the future: if proper soil management is not maintained, all of the additional organic carbon sequestered in the soil will be released back into the atmosphere as carbon dioxide. Therefore, the carbon offsets generated by increases in soil organic carbon would be reversible and only last for the duration of the contract period. This is referred to as the "permanence issue." It is inevitable that such reversible credits will be sold at a high discount compared to carbon offsets generated by permanent reductions. Additionally, the capacity of a soil to continue storing organic carbon is limited (Six et al. 2004; VandenBygaart et al. 2002). Therefore, management options that increase soil organic carbon seem to be viable for curbing greenhouse gases only in the short term - for 10 to 20 years.

Nitrous oxide and methane. In contrast to increases in soil organic carbon, reductions in nitrous oxide or methane emissions are permanent. A reduction in nitrogen application will lead to a permanent reduction in nitrous oxide emissions and so does not pose a legacy problem for the future (Smith et al.

A (Sacramento Valley)

\begin{tabular}{l|c|c|c|c|c|c|c|c|c}
\hline Tillage & Conv. & Cons. & Conv. & Cons. & Conv. & Cons. & Conv. & Cons. \\
\hline Fertilizer & Min. 75\% & Min. & Min. & Min. & Man. & Man. & Man. & Man. \\
\hline Cover crop & No & No & Yes & Yes & No & No & Yes & Yes \\
\hline \multicolumn{1}{c|}{0.0} \\
\hline
\end{tabular}

\section{B (San Joaquin Valley)}

\begin{tabular}{l|c|c|c|c|c|c|c|c|c}
\hline Tillage & Conv. & Cons. & Conv. & Cons. & Conv. & Cons. & Conv. & Cons. \\
\hline Fertilizer & Min. 75\% & Min. & Min. & Min. & Man. & Man. & Man. & Man. \\
\hline Cover crop & No & No & Yes & Yes & No & No & Yes & Yes \\
\hline & & & & & & & \\
\hline \\
\hline
\end{tabular}

Fig. 4. Difference in global warming potential (GWP) emissions for alternative and conventional practices in Sacramento and San Joaquin valleys, and contribution of changes in soil organic carbon (SOC) content versus nitrous oxide $\left(\mathrm{N}_{2} \mathrm{O}\right)$ emissions to overall changes in GWP. Negative values indicate reductions in total greenhouse-gas emissions, emissions of $\mathrm{N}_{2} \mathrm{O}$ or increases in SOC. Conv. = conventional; cons. = conservation; $\min .=$ mineral; $\operatorname{man} .=$ manure.

2007). In our study, when manure was used instead of mineral fertilizer or when less mineral fertilizer was used, nitrous oxide emissions decreased from -0.2 to $-0.49 \mathrm{MtCO}_{2} \mathrm{e} / \mathrm{acre} / \mathrm{yr}(-0.5$ to $-1.2 \mathrm{MtCO}_{2} \mathrm{e} / \mathrm{ha} / \mathrm{yr}$ ). Because these reductions in greenhouse-gas emissions are permanent, they are better solutions in the long term. Avoiding nitrous oxide emissions is in essence about avoiding excess mineral nitrogen in the soil pore water (McSwiney and Robertson 2005). Manure releases nitrogen to the soil system slowly, resulting in better synchronization between the supply of this nutrient and the crop's demand for it. Cutting back on nitrogen fertilizer also decreases the amount of mineral nitro- 
gen in the soil, and has the additional advantage of reducing operating costs.

Fuel use. A similar argument can be made for the fuel-use reduction in conservation-tillage systems. While this extra reduction in emissions may be modest and ranges from -0.1 to $-0.2 \mathrm{MtCO}_{2} \mathrm{e} / \mathrm{acre} / \mathrm{yr}(-0.25$ to -0.50 $\mathrm{MtCO}_{2} \mathrm{e} / \mathrm{ha} / \mathrm{yr}$ ), it is permanent and unlimited because the fuel that is not used in these systems will never be used. In addition, conservation tillage is simple to implement, and generally leads to a direct reduction in costs (Howitt et al. 2009; see page 91).

\section{Making the model more accurate}

There is substantial uncertainty in our model's prediction of how much an individual agricultural field can contribute to a reduction in greenhouse-gas emissions. This uncertainty can range from zero to about double the predicted value. The variability is due mainly to differences in soil characteristics, such as clay content, permeability or organic matter content. If a carbon-offsetting contract combined (or aggregated) different fields, the overall uncertainty would be substantially reduced. Such aggregated carbon-credit contracts will be necessary because the success of a carbon trading system depends on the accuracy of estimates of greenhousegas emissions.

Of all greenhouse gases produced in agriculture, the uncertainty in reductions of nitrous oxide emissions is largest, and often three times the average predicted value. This variability is caused by differences in moisture levels, which control nitrification and denitrification. More research is necessary to further develop the simulation models and make these predictions more accurate.

\footnotetext{
S. De Gryze is Managing Director, Terra Global Capital, San Francisco (during the writing of this article, was Postdoctoratal Researcher, Department of Plant Sciences, UC Davis); M.V. Albarracin is Graduate Student, Department of Land, Air and Water Resources, UC Davis; R. Català-Luque is Adjunct Professor, Department of Economics and Business, CUNEF (Colegio Universitario de Estudios Financieros), and Risk Manager, Banca March, Madrid, Spain; R.E. Howitt is Professor, Department of Agricultural and Resource Economics, UC Davis; and J. Six is Associate Professor, Department of Plant Sciences, UC Davis.
}

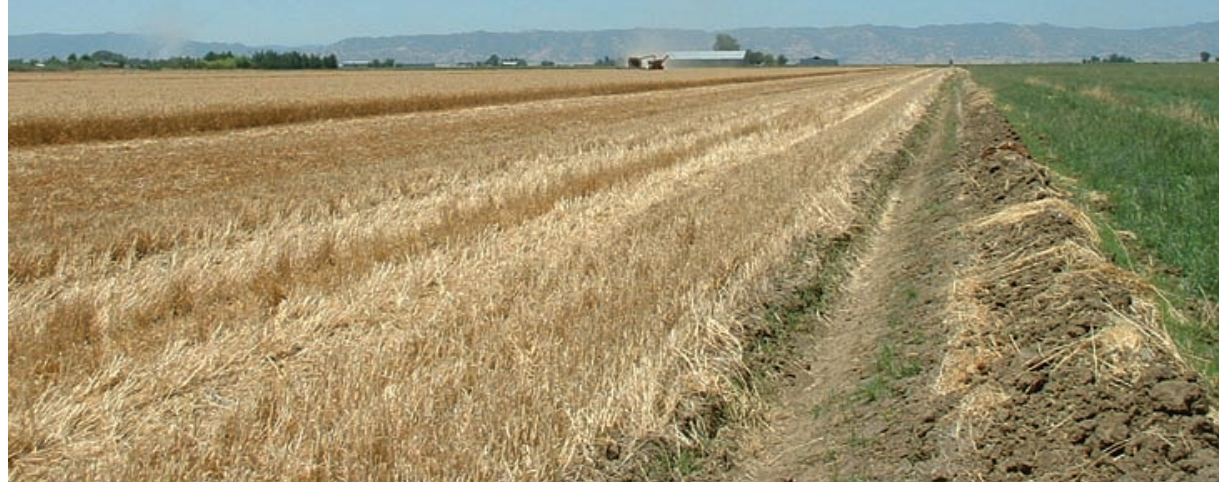

When attempting to quantify how practices in a particular field affect greenhouse-gas emissions, factors such as soil characteristics and moisture levels must be considered. Above, studies at Field 74 near Davis informed the computer model.

\section{References}

Cassman KG, Dobermann A, Walters DT. 2002. Agroecosystems, nitrogen-use efficiency and nitrogen management. Ambio 31:132-40.

Clark MS, Horwath WR, Shennan C, et al. 1999 Nitrogen, weeds and water as yield-limiting factors in conventional, low-input and organic tomato sys tems. Ag Ecosys Env 73:257-70.

Conrad R. 1996. Soil microorganisms as controllers of atmospheric trace gases $\left(\mathrm{H}_{2}, \mathrm{CO}\right.$, methane, OCS, nitrous oxide and NO). Microbiol Rev 60:609-40.

Del Grosso SJ, Parton WJ, Mosier AR, et al. 2000 General model for nitrous oxide and $\mathrm{N}_{2}$ gas emissions from soils due to denitrification. Glob Biogeochem Cycle 14:1045-60.

Denison RF, Bryant DC, Kearney TE. 2004. Crop yields over the first nine years of LTRAS, a longterm comparison of field crop systems in a Mediterranean climate. Field Crop Res 86:267-77.

Deria AM, Bell RW, O'Hara GW. 2003. Organic wheat production and soil nutrient status in a Mediterranean climatic zone. J Sust Ag 21:21-47.

Drinkwater LE, Letourneau DK, Workneh F, et al. 1995. Fundamental differences between conventional and organic tomato agroecosystems in California. Ecolog Applicat 5:1098-112.

Howitt RE, Català-Luque R, De Gryze $S$, et al 2009. Realistic payments could encourage farmers adopt practices that sequester carbon. Cal Ag 63:91-5.

Lee J, Six J, King AP, et al. 2006. Tillage and field scale controls on greenhouse gas emissions. J Env Qual 35:714-25.

McSwiney CP, Robertson GP. 2005. Nonlinear response of nitrous oxide flux to incremental fertilizer addition in a continuous maize (Zea mays L.) cropping system. Glob Change Biol 11:1712-9.
Miguez FE, Bollero GA. 2005. Review of corn yield response under winter cover cropping systems using meta-analytic methods. Crop Sci 45:2318-29.

Mitchell JP, Southard RJ, Madden NM, et al. 2008. Transition to conservation tillage evaluated in San Joaquin Valley cotton and tomato rotations. Cal Ag 62:74-9.

Parton WJ, Schimel DS, Cole CV, Ojima DS. 1987 Analysis of factors controlling soil organic matter levels in Great Plains grasslands. Soil Sci Soc Am J 51:1173-9.

Six J, Ogle SM, Breidt FJ, et al. 2004. The potential to mitigate global warming with no-tillage management is only realized when practiced in the long term. Glob Change Biol 10:155-60.

Smith P, Martino D, Cai ZC, et al. 2007. Policy and technological constraints to implementation of greenhouse gas mitigation options in agriculture. Ag Ecosys Env 118:6-28.

Smith P, Smith JU, Powlson DS, et al. 1997. A comparison of the performance of nine soil organic matter models using datasets from seven long-term experiments. Geoderma 81:153-225.

Snapp SS, Swinton SM, Labarta R, et al. 2005. Evaluating cover crops for benefits, costs and performance within cropping system niches. Agron J 97:322-32.

Stehfest E, Bouwman L. 2006. $\mathrm{N}_{2} \mathrm{O}$ and $\mathrm{NO}$ emission from agricultural fields and soils under natural vegetation: Summarizing available measurement data and modeling of global annual emissions. Nutr Cycl Agroecosys 74:207-28.

[USDA] US Department of Agriculture. 2002. Census of Agriculture - 2002 State and County Reports. National Agricultural Statistics Service. Washington, DC.

VandenBygaart AJ, Yang XM, Kay BD, Aspinall JD. 2002. Variability in carbon sequestration potential in no-till soil landscapes of southern Ontario. Soil Tillage Res 65:231-41. 